\title{
Biological Evaluation of New Schiff Bases: Synthesized from 4-Amino-3,5-dimethyl-1,2,4-triazole, Phenathroline and Bipyridine Dicarboxaldehydes
}

\author{
Md. Shafiqul Islam¹, Mohammad R. Karim1*', William Boadi', Seyi Falekun1, Aminul H. Mirza² \\ ${ }^{1}$ Department of Chemistry, Tennessee State University, Nashville, TN, USA \\ ${ }^{2}$ Faculty of Science, Universiti Brunei Darussalam, Jalan Tungku Link, Gadong, Brunei \\ Email: *mkarim@tnstate.edu
}

How to cite this paper: Islam, Md.S., Karim, M.R., Boadi, W., Falekun, S. and Mirza, A.H. (2016) Biological Evaluation of New Schiff Bases: Synthesized from 4-Amino-3,5dimethyl-1,2,4-triazole, Phenathroline and Bipyridine Dicarboxaldehydes. Advances in Biological Chemistry, 6, 180-192. http://dx.doi.org/10.4236/abc.2016.66016

Received: December 15, 2016 Accepted: December 26, 2016 Published: December 29, 2016

Copyright $\odot 2016$ by authors and Scientific Research Publishing Inc. This work is licensed under the Creative Commons Attribution International License (CC BY 4.0).

http://creativecommons.org/licenses/by/4.0/

\begin{abstract}
Four new Schiff bases with promising anticancer activity have been synthesized from 4-amino-3,5-dimethyl-1,2,4-triazole and di-pyridyl-aldehydes. Structures have been established by various spectroscopic methods. The compounds were tested in vitro to study their cytotoxicity and anti-oxidative activity in human lung carcinoma (A549), breast carcinoma (BT549), prostate adenocarcinoma (PC3) and mouse preadipocytes (3T3-L1) cells. Compound 1 was found to increase Glutathione (GSH) level slightly in all four cell lines. Compound 4 showed better selectivity and cytotoxicity against both BT549 and A549 cells compared to the anticancer drug tamoxifen. With the exception of compound 4 which reduced GSH levels in A549 and BT549, all other compounds maintained GSH levels in comparison to their respective controls.
\end{abstract}

\section{Keywords}

[2,2'-Bipyridine]-5,5'-dicarboxaldehyde, Schiff Bases, Anticancer, Glutathione, Anti-Bacterial

\section{Introduction}

Cancer is the major cause of death in the present world. Approximately 14 million cancer cases was diagnosed and 8.2 million people died because of cancer in 2012 [1] [2]. These numbers are more likely to increase over the following decades [1]. Accordingly, developing new anticancer drugs has become an urgent need. Currently a number of Schiff base and their metal complexes have been investigated as effective scavengers of 
reactive oxygen species (ROS) [3] [4], acting as antioxidants thereby reducing the incidence of certain cancers. Schiff bases form an important class of organic compounds with a wide variety of biological properties.

Chelating agents containing nitrogen are a group of compounds of continuing interests for their ability to interact with biological systems. It is known that the nitrogen rich 1,2,4-Triazole derivatives are a class of compounds that show antitumor [5], anticancer [6], antibacterial [5] [6], antiviral [5], anticonvulsant [5], antifungal [5] [6], anti-inflammatory [5] [6], antituberculous [5], analgesic [6], antimalarial [6] and antidepressant activities [6]. There are several drugs that contain 1,2,4-triazole nucleus such as Letrozole and Anastrozole (anticancer drug), Alprazolam (anxiolytic drug), Rizatriptan (antimigrane drug), Ribavirin (antiviral drug), Itraconazole and Fluconazole (antifungal drug).

Schiff bases and their metal complexes are usually considered one of the most biologically active chemical compounds. The imine bonds or Schiff bases are also found in different enzymes such as transaminases, transketolases and tryptophan synthase to mention a few. Schiff bases synthesized from aldehydes or amines containing heterocyles have been reported to have cytotoxic [7] [8], antiproliferative [9], antibacterial acitivity [8] [9] [10] [11], antiviral [8] [11], antifungal and anticancer activities [11]. For example, Schiff bases and Copper(II) complexes of Schiff bases synthesized from 4amino-3,5-dimethyl-1,2,4-triazole have been reported to inhibit endocytosis [12] and protein tyrosine phosphatases [13] respectively. Triazole containing Schiff bases has also been reported to have antitumor activity [14]. Previous workers in our laboratory had synthesized new Schiff bases containing less flexible, structurally rigid 1,10-phenanthroline backbone, with O,N,S and F-containing amines and studied their antibacterial activity [10]. New Schiff bases have also been synthesized in our laboratory and their antibacterial properties are studied. Since 4-amino-3,5-dimethyl-1,2,4-triazole derivatives have been found to exhibit variety of inhibition properties, we have decided to synthesize various Schiff bases using this 4-amino-3,5-dimethyl-1,2,4-triazole with phenanthroline and bi-pyridyl aldehydes and study their anticancer and antioxidant activities. Particularly, we wanted to test the efficacy of our synthesized Schiff bases in maintaining the antioxidant potential of several cell lines by measuring the effects of the said compounds on levels of glutathione, a natural antioxidant, in cells. Also we have used tamoxifen (Figure 1), a breast cancer drug [15], as our internal standard in comparison to our synthesized Schiff bases for cell viability tests. The structure of tamoxifen is as follows.

Glutathione (GSH) is a tripeptide whose reducing and nucleophilic properties have a vital role in metabolic pathways. GSH has been reported to be the main line of defense for the maintenance of the appropriate mitochondrial redox environment to avoid or repair oxidative modifications leading to mitochondrial dysfunction and cell death [16]. Thiol group of cysteine is oxidized when target molecules are reduced by GSH [16]. GSH also plays an important role in metabolism of xenobiotics, thiol disulfide exchange reactions, cellular signaling such as apoptosis, proliferation and cell-cycle regulation [16]. In this paper, we report the cell viability and oxidative properties of four Schiff 


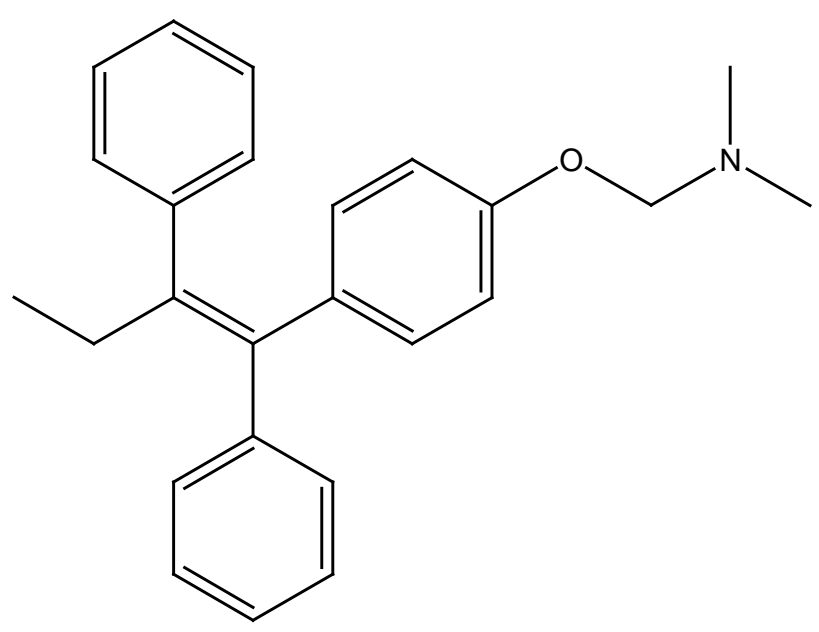

Figure 1. Structure of tamoxifen.

bases on three cancer cells and one obese cell lines.

\section{Materials and Methods}

\subsection{Chemicals and Instrumentation}

All chemicals were purchased from Fisher Scientific, Suwanee, GA and used without further purification. All NMR spectra were obtained on a $400 \mathrm{MHz}$ varian NMR spectrometer. Chemical shifts are given in ppm with TMS as internal reference. All spectra also recorded at room temperature. Mass data was recorded on a Varian LC-MS with ESI.

\subsection{Synthesis of 4-Amino-3,5-dimethyl-1,2,4-triazole (7)}

4-amino-3,5-dimethyl-1,2,4-triazole was synthesized from acetonitrile and hydrated hydrazine in methanol following literature procedure [17]. A mixture of $3.0 \mathrm{ml}$ hydrated hydrazine, $1.5 \mathrm{ml}$ acetonitrile and $1 \mathrm{ml}$ methanol was heated in a $15 \mathrm{~mL}$ Teflonlined autoclave at $120^{\circ} \mathrm{C}$ for 3 days (Scheme 1). The reaction mixture was cooled to room temperature slowly and finally cooled in ice bath. The white crystal product was filtered off. Yield 83\%; ${ }^{1} \mathrm{HNMR}\left(\delta\right.$, DMSO-d $\left.\mathrm{d}_{6}\right): 2.3\left(\mathrm{~s}, 6 \mathrm{H}, \mathrm{CH}_{3}\right), 5.77\left(\mathrm{~s}, 2 \mathrm{H}, \mathrm{NH}_{2}\right) ;{ }^{13} \mathrm{CNMR}$ $\left(\delta\right.$, DMSO-d $\left.{ }_{6}\right): 10.18,151.78$

\subsection{Synthesis of 1,10-Phenanthroline-2,9-dicarboxaldehyde (9)}

1,10-phenanthroline-2,9-dicarboxaldehyde (9) was synthesized form 2,9-dimethyl-1,10phenanthroline hemihydrate (8) following previously reported procedure [18] [19]. Neocuproine hemihydraes $(3.0 \mathrm{~g}, 0.0144 \mathrm{~mol})$ was dissolved in $200 \mathrm{ml} \mathrm{1,4-dioxane}$ containing $4 \%$ water and $\mathrm{SeO}_{2}(6.0 \mathrm{~g}, 0.054 \mathrm{~mol})$ was added and the reaction mixture was refluxed for $6 \mathrm{~h}$ (Scheme 2). Then the reaction mixture was filtered through thick celite pad. Light yellow product was precipitated on slow cooling to room temperature. The product was isolated and dried under vacuum. The crude product was purified by recrystallization in chloroform to get pure compound (Y: 70\%). ${ }^{1} \mathrm{HNMR}\left(\delta\right.$, DMSO- $\left.\mathrm{d}_{6}\right)$ : 


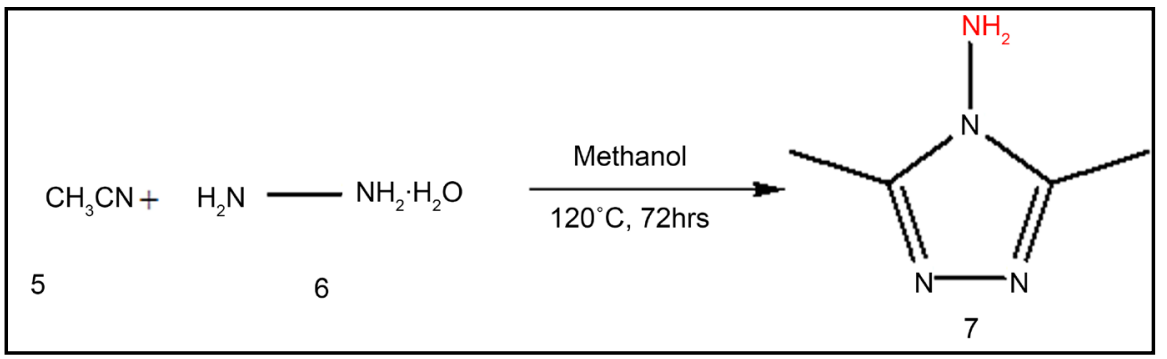

Scheme 1. Synthesis of 4-amino-3,5-dimethy-1,2,4-triazole.

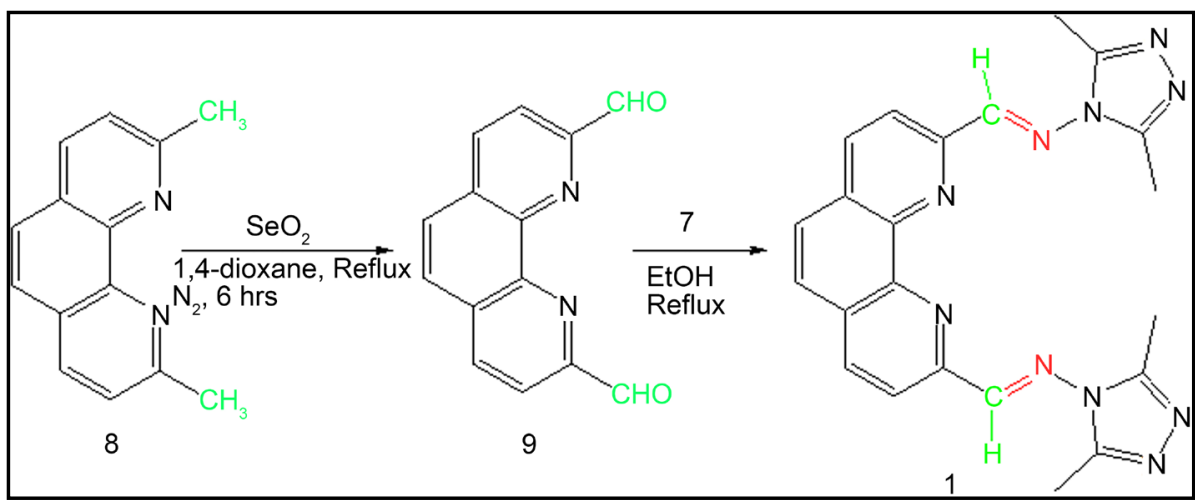

Scheme 2. Synthesis of Schiff base 1 from 1,10-phenanthroline-2,9-dicarboxaldehyde.

10.36 (s, 2H, CHO), 8.9 (d, J ortho $=7.8 \mathrm{~Hz}, 2 \mathrm{H}, \operatorname{Ar}-\mathrm{H}), 8.36(\mathrm{~m}, 4 \mathrm{H}, \operatorname{Ar}-\mathrm{H}) ;{ }^{13} \mathrm{CNMR}(\delta$, DMSO-d $\left.{ }_{6}\right): 194.13,152.68,145.77,138.86,131.95,129.76,120.67$.

\subsection{Synthesis of [2,2'-Bipyridine]-4,4'-dicarboxaldehyde (11)}

[2,2'-Bipyridine]-4,4'-dicarboxaldehyde (11) was synthesized from 4,4'-dimethyl-2,2'bipyridine (10) through direct oxidation by $\mathrm{SeO}_{2}$ under nitrogen condition following literature procedure [20]. 4,4'-dimethyl-2,2'-bipyridine (2.0 g, $0.012 \mathrm{~mol}$ ) was dissolved in $100 \mathrm{~mL}$ 1,4-dioxane containing $4 \%$ water and $\mathrm{SeO}_{2}(4.8 \mathrm{~g}, 0.048 \mathrm{~mol})$ was added and the reaction mixture was refluxed for $48 \mathrm{~h}$ (Scheme 3 ). The reaction was carried out under $\mathrm{N}_{2}$ environment. Then the hot reaction mixture was filtered through a thick Celite pad. The filtrate was kept overnight in dark place to isolate dialdehyde as solid precipitate. The product was isolated and dried under vacuum. The product was further purified by recrystallization in chloroform(Y: 43\%). ${ }^{1} \mathrm{HNMR}\left(\delta\right.$, DMSO-d $\left.{ }_{6}\right): 10.18(\mathrm{~s}, 2 \mathrm{H}$, $\mathrm{CHO}$ ), $9.22\left(\mathrm{~d}, \mathrm{~J}_{\text {meta }}=2.32 \mathrm{~Hz}, 2 \mathrm{H}, \mathrm{Ar}-\mathrm{H}\right), 8.65\left(\mathrm{~d}, \mathrm{~J}_{\text {ortho }}=8.6 \mathrm{~Hz}, 2 \mathrm{H}, \mathrm{Ar}-\mathrm{H}\right), 8.45$ (dd, Jortho $\left.=8.6 \mathrm{~Hz}, \mathrm{~J}_{\text {meta }}=2.32 \mathrm{~Hz}, 2 \mathrm{H}, \mathrm{Ar}-\mathrm{H}\right) ;{ }^{13} \mathrm{CNMR}\left(\delta, \mathrm{DMSO}-\mathrm{d}_{6}\right): 192.96,158.62,151.95$, $138.36,132.19,122.55$.

\subsection{Synthesis of [2,2'-Bipyridine]-5,5'-dicarboxaldehyde (13)}

[2,2'-Bipyridine]-5,5'-dicarboxaldehyde (13) was synthesized from 5,5'-dimethyl-2,2'bipyridine (12) through direct oxidation by $\mathrm{SeO}_{2}$. [2,2'-Bipyridine]-5,5'-dicarboxaldehyde was afforded from the treatment of $5.56 \mathrm{mmol} 5,5^{\prime}$-dimethyl-2,2'-bipyridine with 20 $\mathrm{mmol} \mathrm{SeO}_{2}$ in $40 \mathrm{ml}$ 1,4-dioxane by reflux for $48 \mathrm{~h}$ under $\mathrm{N}_{2}$ environment (Scheme 4). 


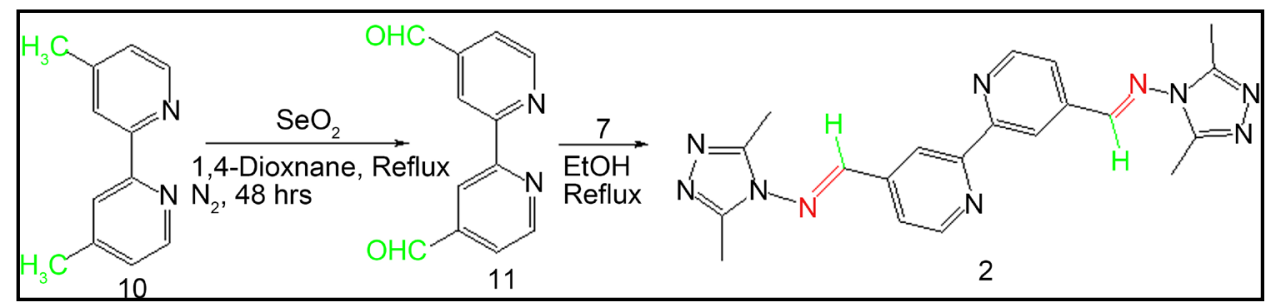

Scheme 3. Synthesis of Schiff base 2 from 2,2'-bipyridyl-4,4-dialdehyde.

Then the hot reaction mixture was filtered through a thick Celite pad. The filtrate was kept over night in dark place to isolate dialdehyde as solid precipitate. The dialdehyde was isolated and dried under vaccum. The pure compound was obtained by washing with hot chloroform (Y: 47\%). ${ }^{1} \mathrm{HNMR}\left(\delta, \mathrm{DMSO}^{-} \mathrm{d}_{6}\right): 10.22$ (s, 2H, CHO), 9.05 (d, $\mathrm{J}_{\text {ortho }}=7.88 \mathrm{~Hz}$, $2 \mathrm{H}, \mathrm{Ar}-\mathrm{H}), 8.8$ (s, 2H, Ar-H), 7.95 (d, J ortho $=7.88 \mathrm{~Hz}, 2 \mathrm{H}, \mathrm{Ar}-\mathrm{H}) ;{ }^{13} \mathrm{CNMR}\left(\delta\right.$, DMSO-d $\left.{ }_{6}\right)$ : $193.81,156.33,151.56,143.31,123.21,119.88$.

\subsection{Synthesis of [2,2'-Bipyridine]-6,6'-dicarboxaldehyde (15)}

[2,2'-Bipyridine]-6,6'-dicarboxaldehyde (15) was synthesized from 6,6'-dimethyl-2,2'bipyridine (14) through direct oxidation by $\mathrm{SeO}_{2}$ following literature procedure [21] [22]. 6,6'-dimethyl-2,2'-bipyridine ( $2.0 \mathrm{~g}, 0.012 \mathrm{mmol})$ was dissolved in $160 \mathrm{~mL}$ glacial acetic acid and $\mathrm{SeO}_{2}(12.0 \mathrm{~g}, 0.12 \mathrm{~mol})$ was added and the reaction mixture was refluxed for $48 \mathrm{~h}$ (Scheme 5). Then the hot reaction mixture was filtered through a thick Celite pad. The filtrate was kept overnight in dark place to isolate dialdehyde as solid precipitate. The product was isolated and dried under vacuum. The crude product was dissolved in hot chloroform and then cooled to room temperature slowly. The impurities precipitated leaving the impurities in solution. The impurities were filtered off and the filtrate was evaporated under vacuum to get pure product (Y: $44 \%) .{ }^{1} \mathrm{HNMR}(\delta$, DMSO-d $_{6}$ ): $10.12(\mathrm{~s}, 2 \mathrm{H}, \mathrm{CHO}), 9.77$ (d, J ortho $\left.=7.92 \mathrm{~Hz}, 2 \mathrm{H}, \mathrm{Ar}-\mathrm{H}\right), 8.3(\mathrm{t}, \mathrm{J}=7.88,2 \mathrm{H}$, $\operatorname{Ar}-\mathrm{H}), 8.05$ (d, $\left.\mathrm{J}_{\text {ortho }}=7.64 \mathrm{~Hz}, 2 \mathrm{H}, \mathrm{Ar}-\mathrm{H}\right) ;{ }^{13} \mathrm{CNMR}\left(\delta, \mathrm{DMSO}_{6}\right): 193.85,155.26,152.55$, $139.65,125.6,122.9$.

\subsection{General Procedure for the Synthesis of Schiff Bases}

$0.5 \mathrm{mmol}$ aldehyde was dissolved in $20 \mathrm{ml}$ hot ethanol or methanol. $1.1 \mathrm{mmol}$ amine 1 was added to the hot solution followed by reflux for $2 \mathrm{~h}$. The reaction mixture was cooled to room temperature and solvent was evaporated under vacuum. Product that obtained was washed with hot acetonitrile to get pure products. Addition of 2 - 3 drops of $\mathrm{H}_{2} \mathrm{SO}_{4}$ increased the yield by at least $5 \%$.

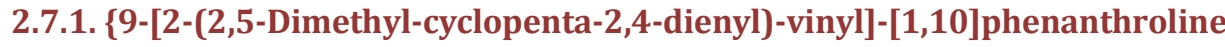 -2-ylmethylene\}-(3,5-dimethyl-[1,2,4]triazol-4-yl)-amine (1)}

${ }^{1} \mathrm{HNMR}\left(\delta\right.$, DMSO-d $\left.\mathrm{d}_{6}\right): 9.13(\mathrm{~s}, 2 \mathrm{H}, \mathrm{Ar}-\mathrm{H}), 8.75\left(\mathrm{~d}, \mathrm{~J}_{\text {ortho }}=8.4 \mathrm{~Hz}, 2 \mathrm{H}, \mathrm{Ar}-\mathrm{H}\right), 8.55$ (d, J ortho $=8.4 \mathrm{~Hz}, 2 \mathrm{H}, \mathrm{Ar}-\mathrm{H}), 8.19(\mathrm{~s}, 2 \mathrm{H}, \mathrm{CH}), 2.55\left(\mathrm{~s}, 12 \mathrm{H}, \mathrm{CH}_{3}\right) ;{ }^{13} \mathrm{CNMR}\left(\delta, \mathrm{DMSO}-\mathrm{d}_{6}\right)$ : $160.28,152.32,148.55,145.48,138.39,130.56,128.85,121.10,11.01$; ESI-MS m/z (\% rel. abund.): $424[\mathrm{M}]^{+}(74), 447[\mathrm{M}+\mathrm{Na}]^{+}(100)$. 


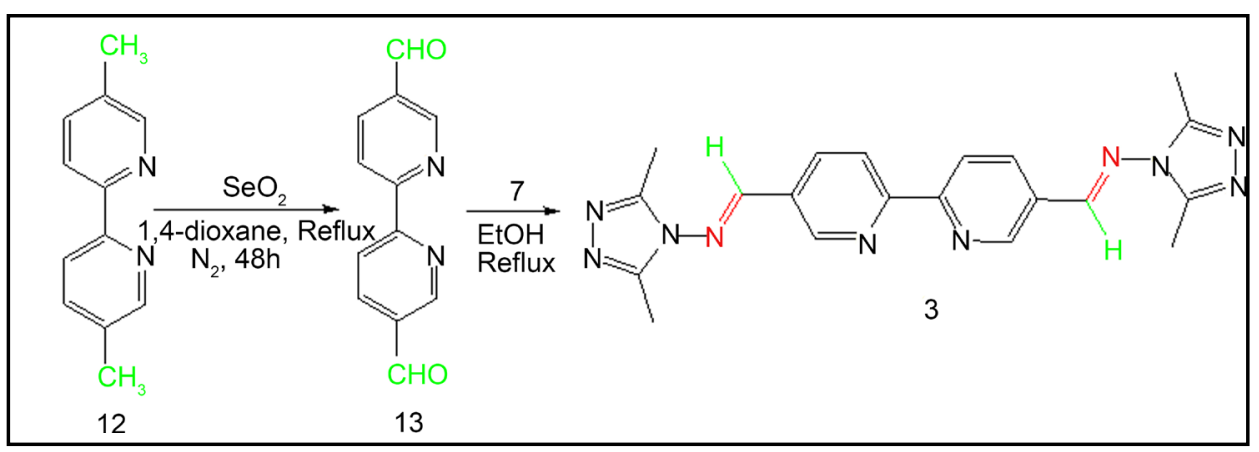

Scheme 4. Synthesis of Schiff base 3 from 2,2'-bipyridyl-5,5-dialdehyde.

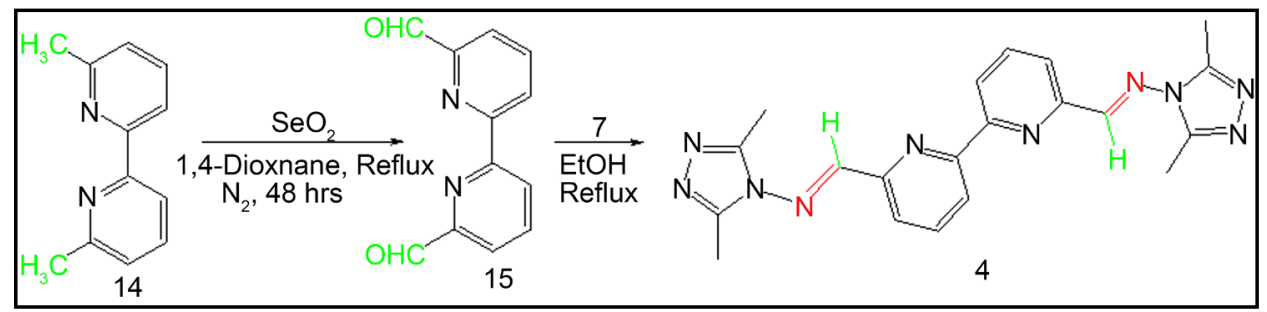

Scheme 5. Synthesis of Schiff base 4 from 2,2'-bipyridyl-6,6-dialdehyde.

2.7.2. \{4'-[2-(2,5-Dimethyl-cyclopenta-2,4-dienyl)-vinyl]-[2,2']bipyridinyl-4ylmethylene\}-(3,5-dimethyl-[1,2,4] triazol-4-yl)-amine (2)

${ }^{1} \mathrm{HNMR}\left(\delta\right.$, DMSO-d $\left.\mathrm{d}_{6}\right): 9.25$ (d, $\left.\mathrm{J}_{\text {meta }}=2.52 \mathrm{~Hz}, 2 \mathrm{H}, \mathrm{Ar}-\mathrm{H}\right), 9.05$ (s, 2H, Ar-H), $8.66(\mathrm{~d}$, $\left.\mathrm{J}_{\text {ortho }}=8.52 \mathrm{~Hz}, 2 \mathrm{H}, \mathrm{Ar}-\mathrm{H}\right), 8.55$ (dd, J $\left.\mathrm{J}_{\text {ortho }}=8.52 \mathrm{~Hz}, \mathrm{~J}_{\text {meta }}=2.52 \mathrm{~Hz}, 2 \mathrm{H}, \operatorname{Ar}-\mathrm{H}\right), 2.44(\mathrm{~s}, 12 \mathrm{H}$, $\left.\mathrm{CH}_{3}\right) ;{ }^{13} \mathrm{CNMR}\left(\delta\right.$, DMSO-d $\left.{ }_{6}\right): 160.53,157.44,150.87,148.09,136.83,129.69,121.88,11.1$; EI-MS m/z (\% rel. abund.): $423[\mathrm{M}+\mathrm{Na}]^{+}(100), 401[\mathrm{M}]^{+}(25)$.

2.7.3. \{5'-[2-(2,5-Dimethyl-cyclopenta-2,4-dienyl)-vinyl]-[2,2']bipyridinyl-5ylmethylene\}-(3,5-dimethyl-[1,2,4] triazol-4-yl)-amine (3)

${ }^{1} \mathrm{H}$ NMR ( $\left.\delta, \mathrm{CD}_{3} \mathrm{OD}\right): 9.00(\mathrm{~m}, 6 \mathrm{H}, \mathrm{Ar}-\mathrm{H}), 8.00(\mathrm{~s}, 2 \mathrm{H}, \mathrm{CH}), 2.60\left(\mathrm{~s}, 12 \mathrm{H}, \mathrm{CH}_{3}\right) ;{ }^{13} \mathrm{CNMR}$ $\left(\delta, \mathrm{CD}_{3} \mathrm{OD}\right): 156.15,157.06,152.68,150.15,139.53,124.87,123.69,11.12 ; \mathrm{EI}-\mathrm{MS} \mathrm{m} / \mathrm{z}$ (\% rel. abund.): $401[\mathrm{M}]^{+}(100), 423[\mathrm{M}+\mathrm{Na}]^{+},(30)$.

2.7.4. \{6'-[2-(2,5-Dimethyl-cyclopenta-2,4-dienyl)-vinyl]-[2,2']bipyridinyl-6ylmethylene\}-(3,5-dimethyl-[1,2,4] triazol-4-yl)-amine (4)

${ }^{1} \mathrm{H}$ NMR $\left(\delta, \mathrm{CDCl}_{3}\right): 8.70(\mathrm{~m}, 4 \mathrm{H}, 2 \mathrm{Ar}-\mathrm{H}, 2 \mathrm{CH}), 8.30$ (d, Jortho $\left.=7.92 \mathrm{~Hz}, 2 \mathrm{H}, \mathrm{Ar}-\mathrm{H}\right), 8.07$ $(\mathrm{t}, \mathrm{J}=7.52 \mathrm{~Hz}, 2 \mathrm{H}, \mathrm{Ar}-\mathrm{H}), 2.8\left(\mathrm{~s}, 12 \mathrm{H}, \mathrm{CH}_{3}\right) ;{ }^{13} \mathrm{CNMR}\left(\delta, \mathrm{CDCl}_{3}\right): 160.26,155.37,150.99$, 148.46, 138.18, 123.69, 121.84, 11.96; EI-MS m/z (\% rel. abund.): $423[\mathrm{M}+\mathrm{Na}]^{+}(100)$, $401[\mathrm{M}+\mathrm{H}]^{+}(20)$.

\subsection{Biological Materials}

All the cell lines were purchased from American Type Culture Collection (ATCC), Manassas, VA. Dulbecco's Modified Eagle's Medium (DMEM), bovine calf serum (BCS) and penicillin-streptomycin were purchased from GIBCO, New York, USA. MTT assay kit, Glutathione assay kit and reduced glutathione were purchased from Calbiochem, California, USA. 


\subsection{Cell Culture}

All four different cell lines were cultured under $5 \% \mathrm{CO}_{2}$ atmosphere at $37^{\circ} \mathrm{C}$ in DMEM supplemented with $10 \%(\mathrm{v} / \mathrm{v})$ BCS and $1 \%(\mathrm{v} / \mathrm{v})$ penicillin-streptomycin following literature procedure [23]. Media was changed in every two days. At $80 \%$ confluence in T-75 flasks, cells were trypsinized with $3 \mathrm{ml}$ of Trypsin-EDTA solution and seeded in either 6 or 96 well plates.

\subsection{MTT Assay}

Cell viability was determined as previously reported [23] [24]. Briefly, $1 \times 10^{4}$ cells/well were seeded in 96-well plates and treated with $100 \mu \mathrm{L}$ different doses $(10,20,30,40,50$, $60,70,80,90,100$ and $200 \mu \mathrm{M}$ ) of the synthesized Schiff bases dissolved in DMSO. The plates were then incubated in an incubator (Thermo Scientific, Marietta, $\mathrm{OH}$ ) at $37^{\circ} \mathrm{C}$, $5 \% \mathrm{CO}_{2}$ for $24 \mathrm{~h}$. following the incubation $0.5 \mathrm{mg} / \mathrm{ml} \mathrm{MTT} \mathrm{(3-4,5-dimethylthiazol-2-yl-2,}$ 3-diphenyl tetrazolium bromide) were added to the wells and incubated at $37^{\circ} \mathrm{C}$ for 4 hours. Supernatants were aspirated and the formazan crystals were dissolved in $100 \mu \mathrm{L}$ DMSO and the absorbance read at $570 \mathrm{~nm}$ in a synergic microplate reader (BioTek, Winooski, VT). The percentage of cell viability was calculated using previously reported formula [20]. The experiments were repeated $3 \times$ with each treatment at 4 replicates.

\subsection{Glutathione (GSH) Assay}

$2 \times 10^{6}$ cells/well for each cell lines were seeded in 6-well plates and cells were treated with 25, 50, 75 and $100 \mu \mathrm{M}$ for each of synthesized Schiff bases and incubated for $24 \mathrm{~h}$ at $37^{\circ} \mathrm{C}$ under $5 \% \mathrm{CO}_{2}$. Supernatants were aspirated and $500 \mu \mathrm{L}$ of Trypsin-EDTA was added and incubated for $5-10$ minutes at $37^{\circ} \mathrm{C}$ to detach cells from wells. $1.50 \mathrm{ml}$ DMEM was added and the cell solutions $(2 \mathrm{ml})$ were transferred to a $2 \mathrm{ml}$ Eppendorf tubes. Cells were pelleted at $3000 \mathrm{x} g$ for 10 minutes at $4^{\circ} \mathrm{C}$ in a refrigerated centrifuge (Thermo Scientific, Marietta, OH). Supernatants were discarded and cells were resuspended in $200 \mu \mathrm{L}$ of $5 \%$ metaphosphoric acid (MPA). Reduced GSH was analyzed according to previously reported method [25]. The cells were sonicated under ice for 30 seconds using a cell dismembrator (Fisher Scientific, Suwanee, GA) at a setting of 3 . Samples were then centrifuged at $4^{\circ} \mathrm{C}$ at $4000 \times \mathrm{g}$ for 8 minutes and the supernatant was used for the GSH analysis as described by the GSH Assay Kit (Cat\# 354102). A standard curve was prepared to calculate GSH levels expressed as nmol GSH/10 $0^{6}$ cells [25] [26]. The experiments were repeated $2 \times$ with each treatment at 4 replicates.

\subsection{Antibacterial Screening Test}

Antibacterial screening test was done using the disc diffusion method [10] [27] [28]. Previously reported procedure [10] was followed to prepare media plate and culture bacteria. Stock solution (10 mg/ml DMSO) was prepared for both synthesized compounds and antibacterial drug tetracycline. Stock solution soaked sterile $6 \mathrm{~mm}$ whatman filter paper was placed in the middle of bacteria spread media plate and incubated 
for $24 \mathrm{~h}$ at $37^{\circ} \mathrm{C}$. Zone of inhibition was measured after $24 \mathrm{~h}$ incubation.

\section{Results and Discussion}

\subsection{Chemistry}

The starting amine 7 was synthesized following previously reported procedure (Scheme 1) [17]. 2,9-phenanthroline-1,10-dialdehyde (9) was also synthesized using literature procedure [18] [19]. The dialdehyde was then reacted with 1 to produce Schiff base 1 (Scheme 2). All product structures were determined by spectral methods. The dialdehyde 11 and 15 have been prepared using previously published procedure [20] [21] [22] following $\mathrm{SeO}_{2}$ oxidation. Dialdehyde 13 has been synthesized previously via multiple step reactions such as bromination of 5,5'-dimethyl-2,2'-bipyridine followed by hydrolysis in acetic acid [29]. In this paper we are reporting an efficient $\mathrm{SeO}_{2}$ oxidation reaction to synthesize dialdehyde 13. Procedure involves the use of 1:4 equivalents of the precursor to $\mathrm{SeO}_{2}$ ratio producing the best yield (47\%). Bipyridylaldehydes (11, 13 and 15) were then subjected to react with amine 7 to produce corresponding Schiff bases 2, 3 and 4 (Schemes 3-5). The synthesis of Schiff bases were carried out in both methanol as well as in ethanol. Higher yields of all four Schiff bases were obtained in ethanol. No reaction occurred in tetrahydrofuran and in chloroform. Solvent Polarity and reflux temperature may have had tremendous effect on Schiff base formation. Addition of 2 - 3 drops of sulfuric acid to the reaction mixture further increased the yield of Schiff bases due to the enhanced nucleophilic attack by amine group of 4-amino-3,5-dimethyl-1,2,4-triazole to carbonyl carbon upon protonation of the carbonyl group. Percent yields of Schiff bases for different reaction conditions are listed in Table 1.

\subsection{Cell Viability Activities in Vitro}

The synthesized Schiff bases were tested to determine their effects on cell viability in A549, BT549, PC3 and 3T3-L1 cell lines using the 3-(4,5-Dimethylthiazol-2-yl)-2,5-Diphenyltetrazolium Bromide (MTT) assay [23] [24] (Table 2). Briefly cells were treated with the respective compounds dissolved in DMSO. Controls containing 2\% DMSO was used as the negative control. The anticancer drug tamoxifen was used as positive control. $\mathrm{IC}_{50}$ for tamoxifen for the A549, BT549, PC3 and 3T3-L1 cell lines were 55, 55, 60 and 35 $\mu \mathrm{M}$ respectively. Compound 4 decreased cell viability in A549 and BT549 cell lines with $\mathrm{IC}_{50}$ values of $70 \mu \mathrm{M}$ and $50 \mu \mathrm{M}$ respectively.

Table 1. Percent yield of Schiff bases 1, 2, 3, and 4 in different reaction condition.

\begin{tabular}{ccccc}
\hline Compound & \multicolumn{4}{c}{$\%$ yield in } \\
\hline & Methanol & Methanol $+2-3$ drops $\mathrm{H}_{2} \mathrm{SO}_{4}$ & Ethanol & Ethanol $+2-3$ drops $\mathrm{H}_{2} \mathrm{SO}_{4}$ \\
\hline 1 & 58 & 63 & 70 & 81 \\
2 & 51 & 61 & 73 & 80 \\
3 & 63 & 74 & 69 & 76 \\
4 & 68 & 81 & 78 & 93 \\
\hline
\end{tabular}


Table 2. Cytotoxic effects of 1, 2, 3 and 4 against A549, BT549, PC3 and 3T3-L1 cell lines.

\begin{tabular}{ccccc}
\hline Compound & \multicolumn{3}{c}{$\mathrm{IC}_{50}(\mu \mathrm{M})$} \\
\hline & $\mathrm{A} 549$ & $\mathrm{BT} 549$ & PC3 & 3T3-L1 \\
1 & $>200$ & $>200$ & $>200$ & $>200$ \\
2 & $>200$ & $>200$ & $>200$ & $>200$ \\
3 & $>200$ & $>200$ & $>200$ & $>200$ \\
4 & 70 & 50 & $>200$ & $>200$ \\
Tamoxifen & 55 & 55 & 60 & 35 \\
\hline
\end{tabular}

However, cell viability did not significantly decrease for compound 4 following exposure to the PC3 and 3T3-L1 cells respectively. On the other hand, tamoxifen was found to have more cytotoxicity against 3T3-L1 cells compared to the A549, BT549 and 3T3L1 cell lines. In addition compound 4 was found to have a better anticancer activity against BT549 with an $\mathrm{IC}_{50}$ of $50 \mu \mathrm{M}$ compared to anticancer drug tamoxifen with an $\mathrm{IC}_{50}$ of $55 \mu \mathrm{M}$. Compound 1, 2 and 3 did not show any significant effects on cell viability in any of the four cell lines tested. These findings suggest that apart from compound 4 which showed some cytotoxic effects to cell lines A549 and BT549, all the others did not affect cell lines tested as well as their anti-proliferative activities.

\subsection{Effects on Glutathione (GSH) Level}

Oxidative stress causes cancer [30], Alzheimer [31], Parkinson [32], infection [33] and heart failure [34]. Glutathione (GSH) plays an important role in the antioxidant status of cells. We measured GSH levels in A549, BT549, PC3 and 3T3-L1 after $24 \mathrm{~h}$ exposure to our synthesized compounds. Table 3 shows the levels of GSH in controls and treated samples for all the four cell lines. Compound 1 increased GSH level slightly for all the doses tested for four cell lines. The increases in GSH for compound 1 from $10 \mu \mathrm{M}$ to $100 \mu \mathrm{M}$ were 1.17, 0.98, 1.51 and 1.89 nMole/106 cells for A549, BT549, PC3 and 3T3L1 cell lines respectively. Compounds 2 and 3 did not have any significant effect on GSH levels for the doses tested. Furthermore, Compound 4 did not have significant effect on GSH in PC3 and 3T3-L1 cells for the doses tested from $0-75 \mu \mathrm{M}$. However, a slight drop in GSH level was noticed for both the PC3 and 3T3-L1 cells following exposure to $100 \mu \mathrm{M}$. GSH levels also dropped significantly for A549 and BT549 for the said compound for all the doses tested. The observed decreases in GSH for the cells for 4 may be due to its cytotoxic effects. Thus, most of the tested Schiff bases did not cause the loss of GSH as shown in Table 3. The above findings may indicate the abilities of these compounds in maintaining and preserving any oxidative damage to the cells.

\subsection{Antibacterial Studies}

Antibacterial screening test of all four Schiff bases were analyzed using both gram positive and negative bacteria. None of the tested Schiff bases was active against $E$. coli MC4100, E. coli DH5a, Listeria monocytogenes, Staphylococcus aureus and Bacillus subtilus. Zone of inhibitions were zero for all Schiff bases tested in all 5 bacteria strains. 
Table 3. GSH level in A549, BT549, PC3 and 3T3-L1 cells after 24 exposure to 2\% DMSO and compounds 1, 2, 3 and 4 .

\begin{tabular}{|c|c|c|c|c|c|}
\hline \multirow[t]{2}{*}{ Compound } & \multirow[t]{2}{*}{ Concentration $(\mu \mathrm{M})$} & \multicolumn{4}{|c|}{ GSH level $\left(\mathrm{nmol} / 10^{6}\right.$ cells) in } \\
\hline & & A459 & BT549 & PC3 & 3T3-L1 \\
\hline \multirow{5}{*}{1} & 10 & 12.88 & 14.83 & 8.08 & 18.42 \\
\hline & 25 & 13.04 & 14.99 & 8.34 & 18.79 \\
\hline & 50 & 13.37 & 15.18 & 8.71 & 19.24 \\
\hline & 75 & 13.88 & 15.43 & 9.11 & 19.88 \\
\hline & 100 & 14.05 & 15.81 & 9.59 & 20.31 \\
\hline \multirow{5}{*}{2} & 10 & 11.66 & 14.69 & 9.01 & 19.13 \\
\hline & 25 & 11.69 & 14.58 & 9.07 & 19.09 \\
\hline & 50 & 11.68 & 14.65 & 8.94 & 19.18 \\
\hline & 75 & 11.63 & 14.72 & 8.99 & 19.18 \\
\hline & 100 & 11.67 & 14.60 & 8.91 & 19.15 \\
\hline \multirow{5}{*}{3} & 10 & 13.17 & 15.17 & 8.6 & 19.01 \\
\hline & 25 & 13.14 & 15.03 & 8.62 & 18.97 \\
\hline & 50 & 13.16 & 15.18 & 8.71 & 18.91 \\
\hline & 75 & 13.21 & 15.24 & 8.64 & 18.99 \\
\hline & 100 & 13.18 & 15.21 & 8.64 & 19.01 \\
\hline \multirow{5}{*}{4} & 10 & 12.53 & 14.39 & 8.22 & 19.21 \\
\hline & 25 & 11.97 & 11.95 & 8.15 & 19.29 \\
\hline & 50 & 6.08 & 6.18 & 8.11 & 19.31 \\
\hline & 75 & 2.98 & 2.06 & 8.19 & 19.15 \\
\hline & 100 & 1.91 & 0.79 & 7.27 & 17.88 \\
\hline DMSO & $2 \%$ & 12.84 & 14.94 & 8.39 & 19.07 \\
\hline
\end{tabular}

\section{Conclusion}

Four Schiff bases have been synthesized successfully and reaction condition for Schiff base preparation has been optimized to better yield. Addition of 2 - 3 drops of sulfuric acid increases the yield by $5 \%-15 \%$. Compound 1 containing rigid phenanthroline backbone may act as an antioxidant since it can increase and maintain GSH levels of cells. Compound 4 exhibited promising anticancer activity with excellent selectivity towards A549 and BT549 over PC3 and 3T3-L1 as opposed to the anticancer drug tamoxifen which killed the cells randomly. To use 4 as an anticancer drug and in clinical studies further studies are anticipated. In conclusion, exposure of several cell lines to different doses of Schiff bases with the exception of one (i.e. compound 4) did not cause significant losses in intracellular levels of GSH compared to their respective controls. The decrease in GSH levels for compound 4 may be due to its cytotoxicity. 


\section{Acknowledgements}

We would like to thank Department of Chemistry, Tennessee State University, USA for necessary support to pursue the research. We are also grateful to the Department of Education, USA, Title III funds for providing necessary instrumental support.

\section{References}

[1] American Cancer Society (2015) Global Cancer Facts and Figures. 3rd Edition, American Cancer Society, Atlanta.

[2] Waghorne, C.L., Corkran, H.M., Hunt-Painter, A.A., Niktab, E., Baty, J.W., Berridge, M.V., Munkacsi, A.B., McConnell, M.J., Timmer, M.S.M. and Stocker, B.L. (2016) N,N-Bis(glycityl)amines as Anti-Cancer Drugs. Bioorganic and Medicinal Chemistry, 24, 3932-3939. https://doi.org/10.1016/j.bmc.2016.04.016

[3] Bala, S., Uppal, G., Kamboj, S., Saini, V. and Prasad, D.N. (2012) Design, Characterization, Computational Studies, and Pharmacological Evaluation of Substituted-N'-[(1E)substitutedphenylmethylidene]benzohydrazide Analogs. Medicinal Chemistry Research, 21, 1-13.

[4] Wu, H., Jia, F., Kou, F., Liu, B., Yuan, J. and Bai, Y. (2011) A Schiff Base Ligand N-(2-Hydroxyacetophenone)-3-oxapetane-1,5-diamine and Its Nickel(II) Complex: Synthesis, Crystal Structure, Antioxidation and DNA-Binding Properties. Transition Metal Chemistry, 36, 847853. https://doi.org/10.1007/s11243-011-9539-2

[5] Sing, G., Sharma, P., Dadhwal, S., Garg, P., Sharma, S., Mahajan, N. and Rawal, S. (2011) Triazoles-Impinging the Bioactivities. International Journal of Current Pharmaceutical Research, 3, 105-118.

[6] Singhal, N., Sharma, P.K., Dudhe, R. and Kumar, N. (2011) Recent Advancement of Triazole Derivatives and Their Biological Significance. Journal of Chemical and Pharmaceutical Research, 3, 126-133.

[7] Tarafder, M.T., Kasbollah, A., Saravan, N., Crouse, K.A., Ali, A.M. and Tin, O.K. (2002) S-Methyldithiocarbazate and Its Schiff Bases: Evaluation of Bondings and Biological Properties. Journal of Biochemistry, Molecular Biology and Biophysics, 6, 85-91. https://doi.org/10.1080/10258140290027207

[8] Sahu, R., Thakur, D.S. and Kashyap, P. (2002) Schiff Bases: An Overview of its Medicinal Chemistry Potential for New Drug Molecules. International Journal of Pharmaceutical Sciences and Nanotechnology, 5, 1757-1764.

[9] Vicini, P., Geronikaki, A., Incerti, M., Busonera, B., Poni, G., Kabras, C.A. and Colla, P.L. (2003) Synthesis and Biological Evaluation of Benzo[d]isothiazole, Benzothiazole and Thiazole Schiff Bases. Bioorganic and Medicinal Chemistry, 11, 4785-4789.

https://doi.org/10.1016/S0968-0896(03)00493-0

[10] Jaman, Z., Karim, M.R., Dumenyo, K. and Mirza, A.H. (2014) Antibacterial Activities of New Schiff Bases and Intermediate Silyl Compounds Synthesized from 5-Substituted-1,10phenanthroline-2,9-dialdehyde. Advances in Microbiology, 4, 1140-1153.

https://doi.org/10.4236/aim.2014.415124

[11] Pignatello, R., Panico, A., Mazzane, P., Pinizzotto, M.R., Garozzo, A. and Fumeri, P.M. (1994) Schiff Bases of N-Hydroxy-n-aminoguanidines as Antiviral, Antibacterial and Anticancer Agents. European Journal of Medicinal Chemistry, 29, 781-785. https://doi.org/10.1016/0223-5234(94)90137-6

[12] Paudyal, R., Jamaluddin, A., Warren, J.P., Doyle, S.M., Robert, S., Warriner, S.L. and Baker, A. (2014) Trafficking Modulator TENin1 Inhibits Endocytosis, Causes Endomembrane 
Protein Accumulation at the Pre-Vacuolar Compartment and Impairs Gravitropic Response in Arabidopsis thaliana. Biochemical Journal, 460, 177-185.

https://doi.org/10.1042/BJ20131136

[13] Ma, L., Zhu, M., Wang, Q., Li, Y., Xing, S., Fu, X., Gao, Z. and Dong, Y. (2011) Mononuclear Copper(II) Complexes with 3,5-Substituted-4-salicylidene-amino-3,5-dimethyl-1,2,4triazole: Synthesis, Structure and Potent Inhibition of Protein Tyrosine Phosphatases. Dalton Transactions, 40, 6532-6540. https://doi.org/10.1039/c1dt10169b

[14] Hu, G., Wang, G. and Duan, N. (2012) Design, Synthesis and Antitumor Activities of Fluoroquinolone C-3 Heterocycles(IV): S-Triazole Schiff-Mannich Bases Derived from Ofloxacin. Acta Pharmaceutica Sinica B, 2, 312-317. https://doi.org/10.1016/j.apsb.2011.11.003

[15] Jordan, V.C. (1993) A Current View of Tamoxifen for the Treatment and Prevention of Breast Cancer. British Journal of Pharmacology, 110, 507-517.

https://doi.org/10.1111/j.1476-5381.1993.tb13840.x

[16] Marí, M., Morales, A., Colell, A., García-Ruiz, C. and Fernández-checa, J.C. (2009) Mitochondrial Glutathione, a Key Survival Antioxidant. Antioxidants and Redox Signaling, 11, 2685-2700. https://doi.org/10.1089/ars.2009.2695

[17] Cheng, L., Zhang, W. X., Ye, B.H., Lin, J.B. and Chen, X.M. (2007) In Situ Solvothermal Generation of 1,2,4-Triazolates and Related Compounds from Organonitrile and Hydrazine Hydrate: A Mechanism Study. Inorgnic Chemistry, 46, 1135-1143.

https://doi.org/10.1021/ic061303i

[18] Thiele, S., Malmgaard-Clausen, M., Engel-Andreasen, J., Steen, A., Rummel, P.C., Nielsen, M.C., Gloriam, D.E., Frimurer, T.M., Ulven, T. and Rosenkilde, M.M. (2012) Modulation in Selectivity and Allosteric Properties of Small-Molecule Ligands for CC-Chemokine Receptors. Journal of Medicinal Chemistry, 55, 8164-8177. https://doi.org/10.1021/jm301121j

[19] Arifuzzaman, M., Karim, M.R., Siddiquee, T.A., Mirza, A.H. and Ali, M.A. (2013) Synthesis and Characterization of New Schiff Bases Formed by Condensation of 2,9-Phenanthroline1,10-dialdehyde with Sulfur-Containing Amines. International Journal of Organic Chemistry, 3, 81-86. https://doi.org/10.4236/ijoc.2013.31009

[20] Gouthaman, S., Periyaraja, S. and Shanmugam, P. (2015) Bipyridine Carbaldehydes as Electrophiles in the Morita-Baylis-Hillman Reaction: Synthesis of Highly Functionalized Bipyridyl Ligands and a Macrocycle. Tetrahedron Letters, 56, 5920-5923. https://doi.org/10.1016/j.tetlet.2015.09.032

[21] Newkome, G.R. and Lee, H.W. (1983) 18[Hexa(2,6)pyridinocoronand-6]: "Sexipyridine”. Journal of American Chemical Society, 105, 5956-5957. https://doi.org/10.1021/ja00356a061

[22] Razzak, M., Karim, M.R., Hoq, M.R. and Mirza, A.H. (2015) New Schiff Bases from 6,6'-Diformyl-2,2'-bipyridine with Amines Containing O, S, N and F: Synthesis and Characterization. International Journal of Organic Chemistry, 5, 264-270.

https://doi.org/10.4236/ijoc.2015.54026

[23] Yang, S.J., Park, N.Y. and Lim, Y. (2014) Anti-Adipogenic Effect of Mulberry Leaf Ethanol Extract in 3T3-L1 Adipocytes. Nutrition Research and Practice, 8, 613-617. https://doi.org/10.4162/nrp.2014.8.6.613

[24] Mphahlele, M.J., Makhafola, T.J. and Mmonwa, M.M. (2016) In Vitro Cytotoxicity of Novel 2,5,7-Tricarbo-substituted Indoles Derived from 2-Amino-5-bromo-3-iodoacetophenone. Bioorganic and Medicinal Chemistry, 24, 4576-4586. https://doi.org/10.1016/j.bmc.2016.07.056

[25] Boadi, W.Y., Lyere, P.A. and Adunyah, S.E. (2005) In Vitro Exposure to Quercetin and Genistein Alters Lipid Peroxides and Prevents the Loss of Glutathione in Human Progenitor 
Mononuclar (U937) Cells. Journal of Applied Toxicology, 25, 82-88.

https://doi.org/10.1002/jat.1049

[26] Rimbach, G., Gohil, K., Matsugo, S., Moini, H., Saliou, C., Virgili, F., Weber, S.U. and Packer, L. (2001) Induction of Glutathione Synthesis in Human Keratinocytes by Ginkgo Biloba Extract (EG761). Biofactors, 15, 39-52. https://doi.org/10.1002/biof.5520150104

[27] Cowan, M.M. (1999) Plant Product as Antimicrobial Agents. Clinical Microbiology Reviews, 12, 564-582.

[28] Cushnie, T.P.T. and Lamb, A.J. (2005) Antimicrobial Activity of Flavonoids. International Journal of Antimicrobial Agents, 26, 343-356. https://doi.org/10.1016/j.ijantimicag.2005.09.002

[29] Hoq, M.R., Karim, M.R. Arifuzzaman, M. and Mirza, A.H. (2015) Synthesis and Characterization of 2,2'-Bipyridyl-5,5'-dialdehyde Schiff Bases from O,S,N and F-Containing Amines. International Journal of Organic Chemistry, 5, 29-36. https://doi.org/10.4236/ijoc.2015.51004

[30] Halliwell, B. (2007) Oxidative Stress and Cancer: Have We Moved Forward. Biochemical Journal, 401, 1-11. https://doi.org/10.1042/BJ20061131

[31] Pohanka, M. (2014) Alzhimer's Disease and Oxidative Stress: A Review. Current Medicinal Chemistry, 21, 356-364. https://doi.org/10.2174/09298673113206660258

[32] Hwang, O. (2013) Role of Oxidative Stress in Parkinson's Disease. Experimental Neurobiology, 22, 11-17. https://doi.org/10.5607/en.2013.22.1.11

[33] Pohanka, M. (2013) Role of Oxidative Stress in Infectious Diseases. A Review. Folia Microbiologica, 58, 503-513. https://doi.org/10.1007/s12223-013-0239-5

[34] Singh, N., Dhalla, A.K., Seneviratne, C. and Singal, P.K. (1995) Oxidative Stress and Heart Failure. Molecular and Cellular Biochemistry, 147, 77-81. https://doi.org/10.1007/BF00944786

Submit or recommend next manuscript to SCIRP and we will provide best service for you:

Accepting pre-submission inquiries through Email, Facebook, LinkedIn, Twitter, etc. A wide selection of journals (inclusive of 9 subjects, more than 200 journals)

Providing 24-hour high-quality service

User-friendly online submission system

Fair and swift peer-review system

Efficient typesetting and proofreading procedure

Display of the result of downloads and visits, as well as the number of cited articles

Maximum dissemination of your research work

Submit your manuscript at: http://papersubmission.scirp.org/

Or contact abc@scirp.org 